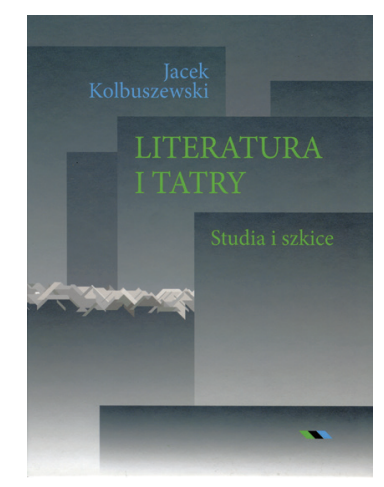

\title{
Wielka księga fenomenów tatrzańskich
}

DOI: $10.19195 / 2084-4107.11 .34$

[rec.:] Jacek Kolbuszewski, Literatura i Tatry. Studia i szkice, Wydawnictwo Tatrzańskiego Parku Narodowego, Zakopane 2016, ss. 752.

Great Book of Tatra Phenomena

Słowa-klucze: Tatry, Podhale, literature, kultura

Keywords: Tatras, Podhale, literature, culture

Literaturoznawcom i przedstawicielom innych dyscyplin naukowych, zainteresowanym problematyką kultury Podhala, dokonania naukowe profesora Jacka Kolbuszewskiego są znane. Nie ulega wątpliwości, że stanowią bezcenną skarbnicę wiedzy i inspiracji twórczych. Od wielu lat autor Tatr $w$ literaturze polskiej 1805-1939 (1982) oraz licznych monografii wpisanych w nurt badań góroznawczych uchodzi za niekwestionowany, najwybitniejszy autorytet naukowy w dziedzinie wiedzy o literackiej karierze gór i ich kulturotwórczej roli. Dlatego z wielką satysfakcją należy odnotować fakt ukazania się jego najnowszej książki (Literatura i Tatry. Studia i szkice). To imponujące opus magnum zawiera kompendium informacji, analiz i refleksji nurtujących autora od dawna i od niedawna. Tematem tej (ogromnie bogatej pod względem poznawczym) książki jest kulturowy fenomen Tatr w literaturze, folklorze, nauce i sztuce. Rozważania o literaturze „tatrzańskiej” (tzn. nacechowanej topiką Tatr) nierzadko postrzegane są w perspektywie komparatystycznej oraz szeroko pojętej antropologii kulturowej, co nadaje im rangę nie tylko literaturoznawczych ustaleń. Charakterystyczna dla warsztatu Kolbuszewskiego interdyscyplinarność ujęcia umożliwia symbiozę 
dyscyplin humanistycznych z przyrodoznawstwem: syntezę wiedzy z zakresu literatury i sztuki, ale też geografii, topografii, turystyki, ochrony środowiska, botaniki, meteorologii, architektury krajobrazu itp. W efekcie — mimo że niektóre fragmenty książki były wcześniej publikowane w formie artykułów i szkiców rozpoznawczych, formułujących wstępne założenia problemu — powstała całość nowatorska, wyznaczająca drogowskazy metodologiczne góroznawstwa jako nowoczesnej dyscypliny naukowej, obejmującej badania nad humanistycznym znaczeniem gór w aspekcie antropologicznym, socjologicznym, filozoficznym, kulturoznawczym. W strukturze książki wyodrębniają się ważne dwa początkowe rozdziały, zawierające próbę definicji i sformułowania wyznaczników celu badawczego analizowanego problemu.

W rozdziale wstępnym „Tatrzański Park Narodowy jako tekst kultury” autor, odwołując się do aktualnego stanu wiedzy, interpretuje definicję tekstu kultury ujawniającego się w przestrzeni (pomniki przyrody) i krajobrazie, otwierając perspektywę dalszych, szeroko zakrojonych studiów nad „długim trwaniem” idei gór w kulturze polskiej. Kolbuszewski sugeruje, że „Park narodowy jako zabytek przeszłości ewokuje [...] myślenie w kategoriach czasu historycznego i na to dostarczyć można wielu dowodów literackich" (s. 33). Stwierdzenie to ważne, nadające rangę faktu empirycznego przeżyciom, których uczestnikiem może stać się każdy górski turysta. W istotnej konstatacji, uzasadniającej potrzebę poszukiwań historycznej roli odkrywania gór, autor potwierdza, że w dziejach kultury turystyka tatrzańska i taternictwo stanowią kluczowe, inspirujące zjawiska: „Kulturowa ważność parku narodowego polega zatem między innymi na zrodzeniu tylko na jego obszarze (gdzie indziej przecież przyroda całkowicie zatraciła już swe pierwotne oblicze, mające moc mitotwórczą) poczucia swoistego utożsamienia czasu teraźniejszego i mitycznej przeszłości. Poczucia »długiego trwania«, na którym polega związek człowieka z ziemią" (s. 33).

Kontynuacją ustaleń teoretycznych jest kolejny rozdział („Góry jako źródło inspiracji artystycznej. Estetyka krajobrazu”), w którym autor, odwołując się do bogatej semantyki krajobrazu, wyznacza kolejne tropy fenomenu gór. Jak pisze Kolbuszewski: „Dopiero odkrycie gór, dopiero zajęcie przez człowieka wobec nich pewnej świadomej postawy (aprobatywnej bądź dezaprobatywnej) sprawia, iż obdarzone zostają pewnymi znaczeniami i stają się pojęciem, by jako owo pojęcie istnieć w sensie zjawiska kulturowego" (s. 47). Podobne konkluzje stanowią fundament budowania nowej metody interpretacyjnej w eksploracjach problematyki górskiej. Tak zatem Kolbuszewski stopniowo „odkrywa” istotne perspektywy analityczne, subtelnie uświadamiając czytelnikowi, że doświadczenia empiryczne i emocjonalne w postrzeganiu krajobrazu górskiego mogą stanowić podstawę tezy naukowej i przekonuje zarazem, że warto ją badać, co ujawnia się m.in. w stwierdzeniu: „Mówiąc zatem o semantyce krajobrazu górskiego, musimy mieć na uwadze sumę znaczeń, jakie zakodowane zostały w krajobrazie przez jego traktowanie jako przedmiotu estetycznego zarówno przez nas samych, jak i przez naszych w górach przez wieki poprzedników" (s. 49). 
Na kolejnych stronicach tatrzańskich szkiców Kolbuszewskiego pojawia się znakomita plejada poprzedników i spadkobierców Stanisława Staszica. Autor prezentuje wędrówkę po Tatrach w literaturze staropolskiej, od poematu opisowego Karpaty Stanisława Jaszowskiego, przez Jana Kochanowskiego, Wespazjana Kochowskiego, Macieja Sarbiewskiego, Benedykta Chmielowskiego i innych. Ponadczasowe tematy folklorystyczne zostały zrealizowane w interpretacji Babiej Góry Kniaźnina — bardzo ciekawym przykładzie górskiej demonologii. Jednocześnie Kolbuszewski ujawnia dowody uniwersalizmu folklorystycznego, obnażając trudności wyodrębnienia typowo rodzimych, regionalnych motywów demonologicznych, ,zagubionych” w imporcie z folkloru innych (nie tylko górskich) regionów.

Intrygujące filologiczne śledztwo zostało przeprowadzone w dwóch szkicach poświęconych „florystycznym drobiazgom”. Podmiotem tych rozważań są rzadko spotykane gatunki roślin, opisane przez Krzysztofa Kluka. Najpierw chodzi o dyptam występujący w rezerwacie „Grabowiec” koło Bogucic. Autor wskazuje jego konotacje biblijne (przywołując gorejący krzew — symbol, przez który Bóg przemówił do Mojżesza), kreśląc dzieje magicznej kariery „rośliny poszukiwaczy skarbów”. Bohaterką następnego rozdziału jest pomcha czerwona, którą Bogusz Zygmunt Stęczyński widział w Karkonoszach. Porost został również opisany przez Stanisława Staszica i Wincentego Reklewskiego, a Kolbuszewski akcentuje jej literacko-kulturowy fenomen

Dalsze rozważania obejmują wiek XIX — niezwykle bogaty w kontekście literackiego fenomenu Tatr. Autor wskazuje doniosłe w znaczeniu symbolicznym i historiozoficznym ujęcie roli Tatr w twórczości Jana Pawła Woronicza, a także przekonująco uzasadnia wpływ Stanisława Staszica na intelektualny dorobek epoki romantyzmu, sugerując, że z księgą Staszica w ręce $(O$ ziemiorództwie Karpatów i innych gór, 1815), wykorzystywaną w roli „swoistej partytury przeżyć - wzorca sposobów emocjonalnego reagowania na piękno krajobrazu — romantyczne pokolenie ruszyło w Tatry” (s. 253). Kolbuszewski „wyławia” romantyczne interpretacje krajobrazu w pismach Staszica, uznanego za prekursora geologii, ale też inspiratora mody na wędrówki w góry.

Znakomitą część książki wypełniają studia górskich pogłosów w twórczości polskich romantyków, zarówno tych najpopularniejszych (Mickiewicz, Norwid), jak i pisarzy zapomnianych (Julian Korsak, Wincenty Pol, Teodor Tripplin). Slawistyczne fascynacje profesora Kolbuszewskiego ujawniają się w szkicu Kartka $z$ dziejów Krywania, otwartym przez znamienne motto z Piosnki o Karpatach

Każda góra ma swą chwałę,

Swe podanie i swój szczyt,

Na nich leżą śniegi białe,

Jakby jakiś wieczny świt.

Wychodząc poza literaturę polską i słowacką, Kolbuszewski wskazuje tatroznawcze akcenty w twórczości Mikołaja Gogola. Obfitująca w literackie i kulturalne wydarzenia druga połowa XIX w. została zaprezentowana w szki- 
cu o Tytusie Chałubińskim (Tytus Chałubiński i jego „Sześć dni w Tatrach”), w którym pojawia się wnikliwa analiza literackiej kariery „odkrywcy” Zakopanego. Podobnie wnikliwa „scjentystyczna” próba odpowiedzi na niewyjaśnione dotąd pytania intryguje w szkicu Witkiewicz jako kolorysta. O sztuce pisarskiej autora „Na przełęczy”. Dwa szkice o Sienkiewiczu podsumowują i uzupełniają dotychczasowe ustalenia badaczy na temat zakopiańskich i góralskich akcentów w pisarstwie autora Trylogii.

W twórczości naukowej Jacka Kolbuszewskiego ważne miejsce zajęły badania nad formacją Młodej Polski Tatrzańskiej. W obszernym dorobku profesora zwracają uwagę m.in. redakcje naukowe BN-owskiej edycji góralskich opowiadań Kazimierza Przerwy Tetmajera (Na skalnym Podhalu) oraz wielu antologii poetyckich o Tatrach. Dlatego warto podkreślić obecność w omawianej książce znakomitych propozycji interpretacyjnych Melodii mgiet nocnych Tetmajera i jego pieśni podhalańskich, eksplikację Na skalnym Podhalu, wędrówkę szlakiem Gorców Władysława Orkana. Heroiczny nurt Młodej Polski (związany z modernistyczną ideą Tatr jako narodowego katharsis i sacrum) został przypomniany w ideowych założeniach Mariusza Zaruskiego. Znajdziemy tam też błyskotliwą refleksję nad Terencjuszowską maksymą Leopolda Staffa „Bo żyłem długo w górach" oraz rozważania antynomii miłości i śmierci w interpretacji Wiatru halnego Tadeusza Nalepińskiego (1914). W każdym z tych szkiców „portretowych” autor, odwołując się do wiedzy i warsztatu literaturoznawczego, próbuje określić istotę fenomenu Tatr zarówno w biografii, jak i poczynaniach artystycznych bohaterów szkicu, wobec każdego z nich wyodrębniając indywidualizm spojrzenia na Tatry. Wchodząc w dwudziestolecie międzywojenne, autor tropi tatrzańskie szlaki Zofii Nałkowskiej, Kornela Makuszyńskiego, na podstawie zachowanych autografów w księdze pamiątkowej kreśli urokliwe wspomnienia kawiarni Franciszka Trzaski, w której bywali nie tylko wybitni i uznani literackiej epoki, ale też popularni artyści, m.in. wirtuoz gry na pile - Alfred Melodysta (uobecniony w poetyckiej egzemplifikacji). Tę bogatą pod względem poznawczym i inspirującą intelektualnie księgę fenomenów tatrzańskich zamyka opis tatrzańskich wycieczek Lenina i charakterystyka literackich dziejów jego kultu (w przywołanej, bardzo ciekawej, egzemplifikacji literackiej pobrzmiewają echa socrealizmu).

Piszącą te słowa wspomnienie Melodysty zainspirowało do dalszych studiów, lecz każdy czytelnik może zostać zainspirowany przez występującą na kartach tej książki obszerną skarbnicę materiału źródłowego. Emanuje z niej niepowtarzalny, erudycyjny i błyskotliwy urok narracyjny, a nade wszystko lekturze towarzyszy zdumienie i podziw dla doświadczonego badacza, który wykorzystując wieloletnie ustalenia - przekazuje spojrzenie nowoczesne, inspirujące dalsze poszukiwania i odkrycia. Kto ciekawy - niech przeczyta z niewątpliwym pożytkiem intelektualnym. Z całą pewnością książka jest niezwykle wartościowym opracowaniem naukowym, ale czyta się ją ,jednym tchem” i jest adresowana nie tylko do naukowców, lecz do wszystkich zainteresowanych miłośników problematyki tatrzańskiej. 
Autor i jego książka 13 sierpnia 2017 r. zostali uhonorowani Nagrodą Literacką Zakopanego (w zmaterializowanej formie statuetki Marcina Rząsy oraz nagrody finansowej), przyznaną po raz pierwszy podczas drugiej edycji Zakopiańskiego Festiwalu Literackiego (w tym roku realizowanego pod hasłem: „Pod Tatry tylko z książką”) przez kapitułę powołaną przez burmistrza stolicy Tatr, Leszka Morulę (tworzyli ją w tym roku: Anna Janko, Tomasz Łubieński, Agnieszka Jurczyńska Kłosok, Paweł Skawiński, Roman Wojciechowski). Jak podkreśliła w swojej laudacji przewodnicząca jury, Anna Janko:

Literacka Nagroda Zakopanego ma wielkie szczęście, że już w pierwszym roku swojego istnienia otrzymuje laureata tej miary co prof. Jacek Kolbuszewski. Jego dzieło, które jako jury uznaliśmy za najlepsze, ze względu na swój europejski zaiste poziom, od razu, jak sądzimy, może sytuować Nagrodę Zakopanego wysoko wśród najbardziej prestiżowych literackich konkursów w Polsce. Trzeba jasno powiedzieć, że takiej monografii i zarazem syntezy tatrzańskiej literatury dotąd w Polsce nie było i - jestem tego osobiście pewna - długo nie będzie.

Wysoka ocena i dowartościowanie tej książki w elitarnym kręgu Zakopanego, określającego ją mianem dzieła wybitnego, jest faktem niezmiernie satysfakcjonującym. To jeszcze jeden powód, by sięgnąć po lekturę.

Matgorzata Łoboz 